


\title{
Ser poeta y mujer: una manera de revelarse y rebelarse en la poesía de Mía Gallegos y Julieta Dobles ${ }^{1}$
}

\author{
Being a poet and a woman: a way to reveal oneself and rebel \\ in the poetry of Mia Gallegos and Julieta Dobles \\ Mayela Vallejos Ramírez ${ }^{2}$ \\ Recibido: 29/9/2016 / Aprobado:1/11/2016
}

\begin{abstract}
Resumen
Este artículo se enfoca en el complejo papel que han jugado las poetas en la sociedad para reivindicar su posición, no solo como escritoras, sino también como pensantes. Específicamente, se ha centrado en la poesía de Mía Gallegos y Julieta Dobles por ser ellas dos sobresalientes ejemplos de tenacidad y excelencia en las letras costarricenses. Se analizan diversos poemas de ambas poetas que muestran la sagacidad con que ellas han creado un espacio propio que les ha permitido obtener un lugar en este espinoso oficio de magas de las palabras.
\end{abstract}

Palabras clave: Mía Gallegos, Julieta Dobles, rebelarse, revelarse, subversión, erotismo

\section{Abstract}

This article focuses on the complex role played by female poets in society in order to claim their position not only as poets but also as thinkers. Specifically, we have focused on the poetry of Mía Gallegos and Julieta Dobles, both extraordinary examples of tenacity and excellence in the Costa Rican letters. We will analyze several poems of both writers that show sagacity with which they have created their own space that has allowed them to obtain a place in this difficult world of literature and made them sorceresses of words.

Key Words: Mía Gallegos, Julieta Dobles, to rebel, to reveal oneself, subversion, eroticism

\begin{abstract}
Sepa una mujer hilar, coser y echar un remiendo que no ha menester saber gramática ni hacer versos.
\end{abstract}

Calderón de la Barca

\section{Planteamientos introductorios}

Ser poeta y mujer ha sido una ardua y complicada labor para muchas mujeres que han tenido que abrirse paso ante el cerrado círculo masculino de poetas que no han apreciado el quehacer literario de la mujer por considerarlas menos aptas para tan ardua tarea, menospreciando de esta manera sus capacidades y sus diferencias. Si se escudriña la situación de las poetas a través de los tiempos, fácilmente se puede comprobar la forma indiferente y hasta condescendiente con que se les ha tratado, como se puede apreciar en el siguiente comentario emitido por Jorge Luis Borges al referirse a Alfonsina Storni: "La señorita Storni se lamenta que se motejen de eróticas sus composiciones - flor, ninfa, amor, luna, pasión cuyo accidental erotismo se acendra vergonzante en símbolos espirituales o se diluye en aguachirle retórica. Yo las encuentro cursillistas más bien. Son una cosa pueril, desdibujada, amarilleja, conseguida mediante el fácil barajeo de palabras baratamente

\footnotetext{
${ }^{1}$ Este texto corresponde con la temática de la ponencia presentada en el II Coloquio Internacional de Investigación y Creación de la Cultura Artística Centroamericana, realizado el 9, 10 y 11 de setiembre de 2015, en el Museo Regional de San Ramón y en la Sede de Occidente, Universidad de Costa Rica, ahora en formato de artículo científico, en versión completa extendida.

${ }^{2}$ Doctora en Literatura Latinoamericana con una especialidad en Literatura femenina y de género. Es profesora catedrática de Colorado Mesa University. Correo: mvallejo@coloradomesa.edu
} 
románticas". (2002, p. 137). Esta situación no ha sido muy diferente para las escritoras costarricenses, las cuales no fueron tomadas en cuenta por la crítica hasta la década de los años 1970 cuando empezó a aparecer una representación insignificante de estas poetas en las antologías nacionales en donde sobresale la laureada escritora Carmen Naranjo (1931- 2012). Cabe resaltar que la lírica costarricense carece de una larga trayectoria en comparación con otros países latinoamericanos. Esa escasez es aún más notable en la poesía escrita por mujeres. Sin embargo, a mediados de la década de los años ochenta surge un mayor número de poetas que buscan construir una poética personal y femenina que represente una nueva conciencia gozosa de ser mujer. En 1994, la Editorial Mujeres publicó una antología denominada Indómitas Voces en donde se hace un merecido homenaje a las poetas entre los siglos XIX y XX. En el prólogo de dicha| antología, se destaca que la "presente selección trata de hacer justicia a voces olvidadas o poco difundidas, de reforzar otras más conocidas e invitar a la lectura de algunas de escasísima circulación o muy reciente surgimiento" (Mora y Ovares, 1994, p.15). Estas mujeres han luchado por darse a conocer en el ámbito literario costarricense y continúan en dicho proceso logrando una mayor aceptación en estos tiempos. En la actualidad, el círculo de poetas costarricenses cuenta con un alto número de destacadas poetas que se han dado a la tarea de demostrar su talento y afianzarse un lugar dentro de este competitivo mundo literario en donde se sobresalen Ana Istarú, Magda Zavala, Lucía Alfaro, María Bonilla, Mayra Jiménez, Paola Valverde y Diana Ávila (Premio Aquileo Echeverría, 2013) solo para mencionar unas cuantas destacadas poetas.

Las poetas a través de la poesía han tratado de explorar en un mundo propio que les permita descubrirse a sí mismas. Esta revelación de su ser íntimo y personal es una forma de rebelarse contra las culturas ideológicas que las han mantenido excluidas de la producción literaria por considerarlas incompetentes para dicha tarea. Gilbert y Gubar consideran que las mujeres son las grandes excluidas de las actividades sociales y culturales lo cual, las expone como seres imperfectos en la sociedad. Estas estudiosas del ser femenino enfatizan en que la mujer "no solo está excluida de la cultura (hecho cuyo emblema podría ser la pluma) sino que también se convierte ella misma, en emblemas de aquellos de Otredad intransigente y misteriosa que la cultura confronta con adoración y temor, amor y odio" (1998, p. 19). Esta concepción es lo que explica el porqué la mujer se encuentra subordinada al hombre. Yadira Calvo manifiesta que "la manera más eficaz para dominar a otros es impidiéndoles la oportunidad de cultivar el espíritu. Esta medida se aplica a las mujeres desde tiempos inmemoriales. Las razones son evidentes: como animal de cría, como muñeca artificiosa y como cocinera sempiterna, le quedaban de sobra los latines" (1993, p. 167). Por esta razón, la mujer se ha visto obligada a adoptar una manera de supervivencia alterna que se manifiesta con "un sometimiento total a restricciones de todo tipo que la redujeron a la condición de inferioridad de que no ha logrado evadirse todavía" (Calvo. 1993: 14). Emilia Macaya reconoce que

La naturaleza y la cultura son categorías ideológicamente construidas bajo el modelo que rige la servidumbre, igual que el señor y el siervo, la cultura domina la naturaleza para ponerla a su servicio. Además, aunque se reconoce que la empresa cultural no es del todo ajena a lo femenino, el cuerpo y la función procreativa parecen poner a las mujeres más cerca de lo natural. La consecuencia última de todo lo anterior es la trampa ideológica que surge por la asociación entre inferioridad, naturalidad, feminidad, la cual está encaminada a consolidad la subordinación de la mujer. (1992, p. 121-122)

Es claro que la situación de las mujeres ha evolucionado con los tiempos, pero aún continúan luchando para labrarse un sitio en los cerrados círculos literarios para demostrar que su capacidad artística es tan buena como la masculina. Si se examina la lista de escritores o ganadores de galardones literarios se puede apreciar fácilmente 
que los hombres ocupan un lugar preponderante a pesar que la sociedad visualiza una mayor paridad entre hombres y mujeres. Al respecto Magda Zavala confiesa que "Todavía sigue siendo mayoritario el grupo de hombres que accede a publicación, así como el que figura en antologías, recibe premios y otros reconocimientos" (Solano, 2015, p.1). Esto se debe en parte a la creencia que la poesía escrita por mujeres no cumple con la calidad esperada dentro del corpus poético.

Al igual que Sor Juana Inés de la Cruz levantó su voz para defender su derecho a versificar, en la actualidad algunas escritoras se rebelan ante esta concepción de inferioridad y exigen que se reconozca que la capacidad de poetizar es independiente del género. La escritora Rima de Vallbona en su artículo la "Trayectoria actual de la poesía femenina en Costa Rica" subraya que "la poesía es siempre poesía independientemente del género que la escriba y que por lo tanto es irrelevante enfatizarla como algo separado" (1992, p. 274). Un criterio similar lo plantea Julieta Dobles cuando expresa en entrevista a Víctor Hurtado que "yo no hago diferencias de calidad entre obras escritas por mujeres o por hombres. Sí existen ciertos temas más frecuentes en las mujeres, como una forma de mencionar la marginación que sufrieron y sufren". (Hurtado, 2014, p.1). En esta misma dirección, la poeta nicaragüense Gioconda Belli en entrevista con Natalia Díaz afirma que "la literatura femenina es un invento masculino. Las mujeres escriben acerca de un universo diferente y con una mirada diferente" $(2015$, p. 2). De la misma forma, Magda Zavala enfatiza que el arte de versificar no es diferente entre los géneros.

"Lo que es cierto es que hay una percepción del mundo que se asocia a cada sexo y al papel de género que pone en relieve datos del mundo y deja del lado o ignora otros" (Solano, 2015, p.1). Lo anteriormente expuesto por estas escritoras muestra en cierta medida la discriminación por la que las mujeres han tenido que pasar, como se puede apreciar en las palabras de Dobles, Belli y Zavala. El hecho que la temática y la manera de percibir el universo sean diferentes, no las hace menos aptas en la tarea de poetizar. Por lo tanto, se rebelan contra lo establecido y se dan a la labor de plantear un mundo nuevo lleno de la visión femenina. La mujer se rebela ante los prejuicios que el mundo le ha impuesto y exige que se le permita explorar el universo con sus propias maneras de concebir el mundo. Las marcas de la feminidad que estructuran estos discursos femeninos suele asociarse con la lucha que estas mujeres tienen contra lo establecido para romper con los pretextos que imponen a la mujer subordinación que les impide competir en el ámbito público.

La poesía escrita por mujeres en Costa Rica ha marcado un nuevo rumbo en el quehacer literario y ha abierto las puertas a un nuevo mundo antes vedado para las mujeres. Ellas se han atrevido a plantear un universo femenino y se muestran los sentimientos más íntimos de su ser, volviéndola personal y poderosa. Magda Zavala manifiesta que:

La literatura escrita por una mujer puede evidenciar diversos estados de conciencia. Sin tener en cuenta la posición conservadora de aceptación de "lo femenino", es posible encontrar tanto la simple presentación de los problemas de género, como la literatura de carácter feminista reinvindicativo y la literatura que muestra a mujeres viviendo de manera alternativa, una vez superados imaginariamente, los obstáculos sociales para su realización. ( 2011, p.19)

Según Octavio Paz, "La poesía es conocimiento, salvación, poder, abandono. Operación capaz de cambiar al mundo, la actividad poética es revolucionaria por naturaleza; ejercicio espiritual, es un método de liberación interior. La poesía revela este mundo; crea otro" (1986, p. 13). Al partir de esta premisa, se puede decir que la lírica femenina costarricense se ha caracterizado por ser una poesía reveladora, que manifiesta lo más íntimo y profundo del ser femenino. Las poetas se han dado a la tarea de crear mundos nuevos muchas veces incomprensibles para una sociedad marcada por el patriarcalismo que no ha concebido una actitud liberadora por parte de la mujer. Esto ha provocado que muchas 
de estas poetas encuentren en su poesía una manera de rebelarse contra las ataduras ancestrales que no les permitían realizarse como seres pensantes. La palabra ha venido a ser el instrumento que les ha reafirmado sus poderes creativos y como magas del verso han podido establecer un espacio propio nacido de la ausencia y la incomprensión. Este proceso espiritual las ha encaminado a la reconquista de un lenguaje con el cual han podido reinventar un espacio completamente femenino.

Para efectos de este estudio se ha escogido a dos extraordinarias poetas: Mía Gallegos (1953) premio Aquileo Echeverría 1985 y Julieta Dobles (1943) cuatro veces galardonada con el premio Aquileo Echeverría y ganadora del prestigioso premio Nacional Magón en 2013. Las dos poetas se manifiestan como mujeres fuertes, aguerridas e intuitivas. Son mujeres dispuestas a continuar con la misión de sus precursoras al reafirmar en la palabra el espacio que se les fue negado en el pasado. Por esta razón, se han escogido cuatro poemas de Mía Gallegos y seis poemas de Julieta Dobles de diversos poemarios de estas dos escritoras que incursionan en la búsqueda del ser femenino colectivo como una extensión de su propio ser. En esta exploración de su identidad, las poetas nos plantean una diversa gama de temas que están relacionados con la hermandad, la visión femenina del Cosmos, la sensualidad y el goce erótico de la mujer. Estas poetas han demostrado que han adquirido el don de la palabra, al reconquistar su cuerpo y afianzar su identidad. Se reconocen a sí mismas como seres pensantes, deseosos de vivir y compartir su existencia con el resto de la humanidad especialmente con su propio género.

\section{Resistencia femenina en Mía Gallegos}

Mía Gallegos (1953) es una poeta intimista, introspectiva y profunda. Su poesía es un ejemplo de la resistencia femenina ante un mundo que le es totalmente hostil. Esto conlleva a que en su poesía se perciba una gran soledad. La cual refleja la búsqueda constante de su propio ser. En palabras de la misma escritora, su poesía "va hacia el lado espiritual, como una búsqueda entrando en mí misma. En ese camino hay de todo, el amor, el miedo ante la muerte, la niñez, la maternidad, la nada muchas veces, el sentir que todo es nada, lo cual es muy desesperanzador. Es como la misma búsqueda dentro del I Ching y el Tarot. En el fondo todo es de característica espiritual. Hay un gran vacío y una necesidad que uno trata de encontrar en diferentes situaciones, o lecturas o gente" (BerryBravo, 1991, p. 146). En esa búsqueda de su ser interior se encuentra a una persona sumamente reflexiva que busca en todas las mujeres del Cosmos su propio ser. Hay una necesidad de hermanarse de alguna manera con todas para ser una y todas a la vez, porque es su manera de trascender y hacer de su oficio un coro de voces femeninas.

Este sentimiento se ve plasmado en muchos de sus poemas como el titulado "Réquiem para Eunice Odio" de su poemario El umbral de las horas (2007). La voz poética abre este poema con un apóstrofe y se dirige a Eunice llamándola hermana, porque ambas han compartido el mismo destino:

Hermana,

puedo llamarte desde la delicia del claustro, hermana, que como yo fue negada,

y por ello saltó,

saltamos juntas

hacia el vacío, hacia la luz. (2007, p. 23)

Se puede notar como este poema trasciende las barreras del tiempo y del espacio porque, aunque nunca se conocieron personalmente, la voz poética siente que son una misma entidad porque han compartido no solo el mismo quehacer literario, sino que también han luchado contra las mismas adversidades. Expresa que ambas han sido incomprendidas en este mundo, pero que dentro de este espacio caminan juntas hacia la luz que es su labor poética. El sujeto lírico más adelante enfatiza,

Sigo tus pasos y trato de evocar la penumbra de tu propio claustro

y del tiempo que hizo

que fueran míos tus pasos ya idos. (2007, p. 23)

La voz lírica ha continuado los mismos senderos de Eunice y se ha encontrado que viven ese claustro, ese confinamiento en que la vida las 
ha puesto por adentrarse en lo prohibido que es la búsqueda del saber. Ella sigue los pasos de Odio porque está convencida que la llevarán a encontrar la iluminación:

Por eso sigo y camino

buscándote como a una hermana

tan apátrida y altiva

tan numeral y estéril

que sólo parecía nacer y renacer

al contacto del fuego y de la llama,

o del aire

quemado en el oficio de la creación. (2007, p. 24)

El arte, la vocación de sacerdotisas de la palabra es lo que las une. En el verso encuentran la salvación y como un fuego purificador pueden saciar sus ansias de ser parte de la creación. Viven en ese cuatro oscuro que ha sido el destino para aquellas que se atrevieron a romper con las reglas impuestas por la sociedad y por eso viven condenadas a la soledad, al destierro espiritual, marginadas de lo cotidiano, pero tiene la certeza que algún día podrán ser aceptadas y comprendidas por la sociedad que las ha alienado por tanto tiempo:

Cómo nacer de ti,

hermana amiga,

desde este claustro a solas

y en oscuros,

en donde, espero se abran

algún día las puertas

y regresar. (2007, p.24)

De igual manera su poema "Mis hermanas" de la misma colección El umbral de las horas (2007) sigue enfatizando ese dolor tan grande que le ha producido el ser poeta y mujer. Ella sabe que en este oficio no se encuentra sola porque ya otras han vivido la misma experiencia. La reconforta saber que es gracias a ellas que puede resistir los embates que le da la vida:

Otras mujeres, que, como yo, tampoco debieron nacer, me acompañan. Escucha sus nombres vanos tal vez a ti no te digan nada, pero ellas son de la misma estirpe maldita maldecida, negada, oscurecida. (2007, p.91)
La voz poética se dirige al lector, haciéndole notar que esas mujeres que la acompañan en su destierro, probablemente le sean indiferentes; ya sea por falta de conocimiento o por no comprender el drama que estas mujeres vivieron en su época. Pero ellas, al igual que el sujeto de la enunciación, fueron incomprendidas por la sociedad. Enumera a cada una de estas mujeres, entre las que se encuentran Sor Juana, Eunice Odio, Yolanda Oreamuno, Alfonsina Storni y muchas otras que marcaron una diferencia en la historia de la humanidad pero que tuvieron que pagar un terrible precio por irrumpir en el mundo masculino: "Siempre habrá un poder masculino/y cruel que nos acabe" (2007, p.92). La voz lírica encuentra en esas mujeres su familia porque comparte con ellas la misma sangre y el mismo destino:

Somos las parias, las mujeres hechiceras que en cada siglo aparecen para ser castigadas quemadas

incineradas,

olvidadas. (2007, p 93)

La voz poética se solidariza con estas poetas porque pertenece a la misma estirpe y debe continuar con la misión de ser poeta y ser mujer:

Y ellas me piden escribir

para disentir

para increpar.

Y no me rindo" (2007, p. 94).

La poeta continúa con esta ardua tarea a pesar de los obstáculos que se le presentan en la vida. Esa ha sido siempre la situación que todas han tenido que confrontar y Gallegos va a continuar levantando el estandarte de la lucha porque se lo debe a sus hermanas.

Entonces su misión como poeta, la lleva a indagar dentro de sí otras posibilidades que revelen su ser interior, que la definan y la afirmen como un ser pensante y actante porque las reglas patriarcales solo le han permitido conocer su ser interior. Le han impuesto la mudez como lo expresa en su poema "Reino": 
Me enseñaron

el arte del silencio

También se me indicó con gestos

que era menester responder

con nobleza frente a la adversidad.

Cumplo con la promesa de callar. (2007, p. 31)

Las mujeres a través de la historia de la humanidad han vivido mayormente en silencio obedeciendo unas reglas que fueron creadas por otros para mantenerlas sujetas a principios que muchas veces les son incompresibles pero que normalmente obedecen sin cuestionar. La voz poética aquí dice que aprendió a guardar silencio porque "Yo sé que manda quien conquista. /Y yo soy una mujer y no una guerrera. /Callo. Me callo. Resisto (2007, p.32). Este aspecto deja apreciar claramente que muchas veces las mujeres no pueden luchar abiertamente contra las leyes impuestas por la sociedad patriarcal y no tienen más remedio fingir que obedecen las imposiciones, pero en realidad "el silencio femenino intenta redefinir el mundo" (Macaya, 1992, p.125). Dentro de ese mundo invisible para el patriarcado, la mujer se define como lo que es, un ser humano con los mismos derechos y necesidades.

De ahí, la necesidad de auto-reafirmarse cuando dice "Hija de la tierra soy/ Amante de la muerte. / A menudo en mis sueños la verdad se revela por completo" (1985, p.15). Ella sabe quién es y qué papel le ha correspondido desempeñar en esta vida, pero pide que se le deje ser parte del universo y despeñar un papel mucho más activo "Deja que sea yo quien te penetre. Aunque sea por una sola vez" (1985, p.15). En la voz lírica se revela la necesidad de jugar el papel masculino, aunque sea por una sola vez y degustar el poder que nunca la ha pertenecido: "Déjame entrar en ti. Tú eres el todopoderoso/ masculino. Yo soy la otra verdad" (1985, p.16). En otras palabras, la mujer también es parte de este universo, aunque las leyes patriarcales se hayan empeñado en encarcelarlas en un mundo pequeño. "La mujer, encerrada en el espacio mínimo del mundo privado, ha ido descubriendo la fuerza subversiva de un nuevo discurso gestado en el silencio" (Macaya, 1992, p. 125). Su propia intuición las ha llevado a explorar en su interior y quitarse las máscaras que han tenido que llevar a través de los tiempos para poder ser parte activa del mundo.

Otro aspecto en la poesía de Mía Gallegos es que, a pesar de la soledad, de la desesperanza y del escepticismo en relación al sexo masculino, muchos de sus poemas manifiestan en ella ese deseo de vivir en una gran armonía: "El amor que busco es el de la unidad, el de la armonía y el gozo. /Ese que se cumple cuando un hombre y una mujer pueden mirarse por completo" (2007, p. 33). Esta comunión espiritual entre un hombre y una mujer se vislumbran casi siempre como un sueño, como algo inalcanzable porque "Los hombres son así, / como Ulises, / siempre se marchan y nos dejan/ con la mirada perdida/ detrás de las ventanas" (2007, p. 109). La voz poética siente que su destino al igual que el de Penélope es vivir a la espera de que el varón regrese. Por su incapacidad de tejer usa la única arma que la puede ayudar a aminorar la espera: "Esta es mi Odisea, / escribir así imaginando que alguien regresa, y mientras tanto moro en mí, me habito" (2007, p.110). Se va conociendo a sí misma $\mathrm{y}$ fortaleciendo con la espera.

En resumen, la poesía de Mía Gallegos refleja sentimientos encontrados en donde se debate su situación como mujer y su compromiso como poeta. Y solo en la palabra encuentra su fortaleza y su capacidad de darle nuevos rumbos al tiempo que le tocó habitar. Es desde su escritura, desde "su claustro elegido" como lo indica en el poema que lleva su mismo nombre que ella encuentra la fortaleza y la inspiración para continuar viviendo: "Busco la intensa reflexión:/la de los libros amigos, /la luz interna que necesito para vivir, /el candil de oro, / el Eclesiastés y la paciencia de Job”. (1989, p. 29). Esta autoafirmación se ve presente en muchos de los poemas de Gallegos para reencontrarse consigo mismo y reafirmar su identidad, como bien lo explica Jorge Chen Sham en su estudio "El autorretrato en Mía Gallegos: la invención de sí misma": "De esta manera, en el siglo XX, en ese momento en que la conciencia de las mujeres las conduce a buscar su propia escritura, muchas poetas empezarán a hacer autorretratos, signo de autoafirmación y de una búsqueda identitaria que sobrepasa cualquier tendencia de género" (2003, p. 100). 


\section{La poesía humanista de Julieta Dobles}

En Julieta Dobles se encuentra otro tipo de poesía. Si bien es cierto que conserva lo íntimo y lo personal de la poesía de Gallegos, esta es más diáfana $\mathrm{y}$ ante todo, llena de una simpleza profunda por el universo que en que se habitan las personas y por los quehaceres del ser humano. No sorprende, por lo tanto, que esta laureada poeta costarricense esté catalogada por la crítica nacional y extranjera como una de las mejores y más representativas poetas contemporáneas costarricenses. Carlos Duverrán considera que Dobles "es una de las voces poéticas más representativas de su generación. Su poesía de claras intuiciones expresa su sentir hacia el mundo, lleno de significados humanos" (1973, p. 287). En Dobles, se aprecia una magia profunda, cargada de riqueza espiritual. Su sólida trayectoria literaria nos muestra una amalgama de poemarios en donde se aprende a caminar de la mano de la voz poética un camino hacia la iluminación. Esta poeta cuenta con quince poemarios hasta el momento. Cada una de estas colecciones toca aspectos distintivos de la vida porque es una poética siempre muy personal e intimista. Sus primeros poemarios son de corte vanguardista y hacen un mayor énfasis en la vida misma, la naturaleza y empiezan a marcar ese aspecto auto-vivencial que es tan latente en su obra, como se ve claramente expresado en sus cuatro primeros libros Reloj de siempre (1965) El peso vivo (1968), Los pasos terrestres (1976) y Horas de lejanías (1982).

Es con Los delitos de Pandora (1987) que Dobles hace un alto en su estilo y temática para incursionar en un mundo femenino. Es un libro único, sui generis dentro de su poética. Por primera vez, la poeta toca un tema exclusivamente de corte feminista. Julieta Dobles se colocó a la vanguardia femenina para hacernos copartícipes de otra versión de los hechos.

Dobles explains her experimentation with a new theme and style. The poems in this collection can be classified as her first openly feminist work. In them she poeticizes the history of women through the presentation of the mythical Pandora, whose desire for knowledge causes her to open the forbidden box. Dobles expresses the necessity for women to have their voices and to write their own history, as opposed to allowing their stories to be controlled by men. (Budd, 2003, p.105)

Lo más sobresaliente de esta colección es que la poeta no plantea la situación de la mujer con sarcasmo o con ironía. Dobles nos muestra una visión femenina en donde la mujer aprende a descubrirse a sí misma desde adentro. Esto lo logra por medio de la intertextualidad y la reescritura, cuestionando el pasado y ensalzando el quehacer femenino: "En una retrospectiva sobre las diferentes temáticas que sus obras han cobijado la poeta destaca por ejemplo a la mujer en Los delitos de Pandora (1987). Afirma que el pasado está lleno de injusticias para la mujer sometida al patriarcado brutal; pero cambios formidables se logran desde la segunda mitad del siglo XX gracias a la lucha de muchas mujeres y de la revolución que propició el feminismo, a pesar de algunos errores y abusos" (Peña Bonilla, 2014, p.1). Dobles no pretende cambiar la historia sino plantearnos otra perspectiva. Es la versión en donde se da vida a la palabra femenina que ha permanecido secuestrada por los siglos. Dobles considera que se debe entrar al tiempo moderno con las conciencias llenas de esa memoria y así revestirlas con un nuevo ropaje. $\mathrm{Su}$ argumento en estos poemas muestra un nuevo camino para borrar viejos cánones preestablecidos para que no continúen afectando la visión de futuras generaciones, ya que con ello se margina a la mujer, dejándola sin libertad para crecer. De la primera parte del poemario, se trabajará el segundo poema "Saga sin tiempo". Este poema hace alusión al papel esencial que ha jugado la mujer en el transcurso de la humanidad. El poema está dividido en cuatro partes. En las tres primeras, se juega con la dualidad de los hechos. Estas alusiones sugieren que la poeta quiere resaltar lo que la mujer ha sido realmente y como se le ha juzgado injustamente a través de la historia de la humanidad. La voz lírica abre el poema diciendo: "Y así fue desde entonces" (Dobles 1986: 25). De 
ahí que sea una saga sin tiempo porque este es un sendero que han caminado todas las mujeres a través de la historia de la humanidad. En cada uno de estos versos ensalza las labores diarias que contribuyeron para crear el mundo que ahora se conoce. Pero a pesar de su ardua labor, las mujeres han sido consideradas inadecuadas, incapaces e indignas para desempeñar trabajos destinados para el varón:

\section{Te encontraron indigna \\ de acercarte a los dioses \\ y avivar el brasero \\ en tus puertas oscuramente hostiles, \\ a ti, que escuchas \\ el lenguaje implorante de la vida, \\ de los múltiples seres \\ que se debaten desde su ribera. (1986, p. 29)}

En estos poemas se trabajan especialmente tres estereotipos femeninos: inferioridad, sumisión y sensibilidad. Los dos últimos dependen de la concepción del primero. La creencia de que la mujer es inferior la ha llevado al sometimiento del varón. Su condición de mujer las coloca en una situación desventajosa porque ellas habitan un mundo diferente que las separa de los hombres. La sensibilidad, la intuición, la maternidad se volvieron en contra de la mujer por una visión patriarcal incapacitada de maravillarse de la diferencia:

Te encontraron indigna

porque tienes la sensibilidad a flor de piel/

y eres la otra mitad

del hechizo creador

con que la vida marca

para seguir la vida. (1986, p.29)

Pero la voz poética les asegura que sus sacrificios no han sido en vano porque

La fuerza que nadie miró en ti,

hierba bajo la losa,

medida de los sueños ignorados,

fue creciendo, alimentándose de tus silencios, de tu mínima noche

hasta hacerse inabarcable y feraz. (1986, p. 30)
Y ella ahora retoma esa fuerza, y esa palabra:

Yo, que asumí tus pasos

donde te fue imposible continuar,

yo la favorecida de tus sueños,

asumo tu misión de siempreviva. (1986, p. 31)

En este poema, el sujeto de la enunciación desde la primera persona singular engloba un nosotros colectivo para ofrecerles su voz a mujeres que nunca tuvieron voz. La voz lírica reconoce el valor y la grandeza que hay en cada una de las mujeres y como esa fuerza se traspasa cósmicamente de generación en generación para mantener la unidad y solidaridad:

Yo, que hoy vengo de un tiempo

tan lejano del tuyo

como la estrella antigua que aún nos llega

y que explotó hace siglos

en un confín de Andrómeda (1986, p.31).

Dobles quiere formar parte de este poema porque la mujer pese a todos los sufrimientos e injusticias ha podido permanecer, renaciendo a cada instante en las miles de Pandoras que transitan por el mundo. La voz poética también reconoce que, gracias a los sacrificios hechos por miles de mujeres a través de la historia, ella ahora tiene la oportunidad de desarrollarse en la sociedad con mucha más libertad que lo que sus antepasadas pudieron lograr.

El próximo poemario que marca un fuerte cambio en la poesía de Dobles es Amar en Jerusalén (1992). Se escogió porque este poemario permite apreciar claramente otra etapa de la vida de Dobles como poeta y mujer. Este compendio de poemas habla de amores contrariados, traicionados, reconciliados. Abre su alma para presentarnos el dolor tan profundo que deja la traición de un ser sumamente amado en el cual se ha cifrado toda la esperanza de una vida juntos. Ruth Budd parafraseando a Mayra Herra apunta que:

Herra explains that although on this collection are at times painful to read because of their intimate revelations, this honesty makes a powerful impact on those who experience them. This assertion is especially true 
for female readers, who, because of the poet's willingness to expose unfiltered her own trauma, can feel a sense of personal identification with the betrayal and pain so evident in the relationship describe in Amar en Jerusalen. (2003, p. 105)

Es notable en estos poemas, los deseos imperiosos de la hablante poética por salvar una relación de toda una vida. La angustia que produce saber que se está muriendo el amor. La pena que causa el desamor sobre todo cuando se percata que lo que tan íntimamente se compartía antes con el ser amado, ahora lo comparte con otro ser. Este sentimiento está claramente descrito en muchos de los poemas de esta colección. En fin, lo que presenta este poemario es una relación en crisis como se aprecia en el poema "Peligro de muerte":

Se nos muere de frío, esposo,

y de todas las hambres de la ausencia.

Yo lo oigo llorar en las noches vacías

Desconsoladamente solo,

Transparente y dolido

Como un niño en su muerte (1992, p. 7)

La voz poética lucha por revivir ese amor que ella considera que no merece morir por todos los años que fueron felices, compartiendo las alegrías y las tristezas. Fueron plenamente dichosos y crearon un hogar que parecía sólido. Por lo tanto, vale la pena luchar para darse una segunda oportunidad:

Déjame rescatarlo de éstas,

Nuestras manos ingratas y sombrías

Y volverlo a la vida,

Que me voy yo con él,

Si él se me acaba. (1992, p. 9)

Nótese aquí la gran angustia que siente la voz lírica al imaginar la perdida de ese hombre tan amado. El poema concluye con una súplica a su compañero. Desea que le permita intentar salvar la relación, porque ella no sabría qué hacer sin ese amor.

Estos son probablemente los poemas más dolorosos que haya escrito Dobles, pero a la vez sumamente emotivos. En ellos se siente toda su intimidad a flor de piel. Es capaz de abrirse completamente para tratar de exorcizar estos sentimientos encontrados que la están matando por dentro. En otras palabras, son unos poemas escritos con el alma. Los cuales dejan una huella muy honda en el alma del lector. La sensibilidad es tal en este poemario que la poeta en su búsqueda por encontrar una respuesta al desamor dedica un poema a la otra, a esa mujer por la cual ha sido traicionada. Para admiración del lector, este poema está compuesto con imágenes sensibles y delicadas:

Mujer de muchos nombres, nombres dados por mí

al furtivo silencio de los días como años, a tu presencia tenue en los ojos y la voz de mi amando,

a la angustia violenta

de mis celos primigenios y fúlgidos

como una llamarada

bajo el ala doliente de mi pecho.

Si pudiera, hermana, sombra mía en el cuerpo de mi esposo, que compartes conmigo su aroma secretísimo, su forma de besar, frutal y triunfante, pero plena de tiernos adjetivos feroces. (1992,p.19)

La otra, la cual normalmente se detesta y se aborrece, en este poema está descrita de una manera elegante porque en su grandeza espiritual, la voz poética se atreve llamarla su hermana. No la insulta porque ellas comparten algo muy amado y han pasado a ser una extensión de la otra: "Hermana, /te conozco a través de sus sueños/ como a mis propios sueños.../una misteriosa manera de ser yo misma otra, /repitiendo el amor. (1992, p.21). Esto nos deja ver claramente que la poesía de Dobles es una poesía sumamente intimista que revela a cada paso lo más profundo de su ser. A la vez, nos deja ver su franqueza y su plena realización como mujer porque se atreve a poetizar en temas tabú para el ser humano.

En esta colección de poemas también se encuentran unas imágenes muy sensuales y provocativas que más adelante van a tomar mayor fuerza en su poemario Hojas furtivas (2007). El 
poema "Fotografía en tu ausencia" de la colección de Amar en Jerusalén (1992) es la introducción perfecta para esta colección de |corte erótico. En este poema, la voz lírica nos plantea el mito de la sexualidad femenina y el papel que ella debe ocupar en la sociedad para ser considerada respetable especialmente cuando entra en la etapa madura. A lo cual la voz poética responde:

Se supone que una dama respetable cuyos negros cabellos sufren ya de estrellas en las sienes, cuyos hijos inician la partida definitiva y solitaria, el nuevo nacimiento hacia sus territorios interiores y únicos, debe cumplir, con solemne premura, el ritual de las Labores Diarias, así, muy específico, y sin alas azules, ni canción inventada sobre el beso que asalte las almohadas aún tibias o el regazo. Deber llevar su Agenda Cotidiana, en donde no germinen los claveles salvajes, ni corra el viento, ni se llenen de perfume enervante la fecha o la palabra. (1992, p. 19)

La voz lírica se rehúsa a renunciar al placer físico, a un sentimiento que la mantenga viva, vibrante porque sigue deseosa de amar y ser amada. Le resulta insuficiente un rol limitado a la agenda cotidiana; no se conforma con jugar el papel que por siglos ha tenido que aceptar la mujer: "Nos quedamos dentro de la casa, con nuestra sexualidad ciega, sorda, muda, entrada en el silencio y la resignación. El cebo del placer unido al anzuelo de la reproducción nos condenó a no conocer nuestras necesidades, nuestro cuerpo, y a "ser" en función de reproducir hijos; productoras eficientes y calladas, cuidando y atendiendo a los otros por encima de la propia satisfacción" (Lerer, 2004, p. 27). A pesar que la poeta ama su rol de madre, no renuncia a su intimidad y menos aún a su goce personal: "Mis hijos han crecido/hacia el fragor del mundo,/ y marchan por sus vidas/admirados, agridulces, plenarios, /y sigue intacto mi deseo" (Dobles, 2007, p. 29). Ella cree que como mujer tiene el derecho de seguir amando y sintiéndose sumamente amada por su compañero. El hecho de envejecer no significa que se pierdan los deseos ni las necesidades biológicas como se empeña la sociedad patriarcal en enfatizar.

Por esta razón en su poemario Hojas furtivas (2007), la poeta llena las páginas de imágenes sensuales y de goce erótico como una forma de redefinir su cuerpo femenino. La poeta no se avergüenza de su cuerpo, de sus emociones y mucho menos de su edad avanzada. Por el contrario, muestra una gran madurez y un deseo de explorar en lo prohibido. Es una manera subversiva y empoderadora para la mujer. "Hojas furtivas nos comunica que el cuerpo es una simbiosis entre el sentimiento interior y el sentimiento exterior, una dimensión de la experiencia entre el hombre y el mundo. Esa gloria que se encuentra cuerpo a cuerpo mientras la luz se desnuda, así vemos cómo las ensoñaciones hacen brotar una serie de imágenes cuya plástica imaginaria fluye en nuevas emociones, las cuales incluso alcanzan extensiones ilimitadas como una "catarsis sanadora" (Madriz Flores, 2009, p. 154).

Estos poemas expresan un erotismo cósmico en donde el cuerpo de la mujer se presenta como una fuente infinita de poder y de placer para ella y su amado como se puede apreciar en el poema "Mi única guerra":

Aventurar mi lengua en tus rincones.

Beber morosamente

los riachuelos salinos

que recorren tu piel

en la hora el delirio.

Y celebrar al tacto

las duras colinas sorprendidas,

que en tus muslos y brazos

se tensan bajo la voluntad

de mis manos deseantes. (2007, p.27)

Se observa el uso de las imágenes descriptivas y sugestivas de una unión plena en donde la voz poética vive pletóricamente su relación amorosa. No hay miedo de expresar los sentimientos y mucho menos reservas en describir con palabras sus deseos. 
El alma está abierta de par en par, ávida de amar y ser amada. En "Sábanas por lavar" se puede apreciar el aspecto sensorial. La voz poética quiere seguir disfrutando de su encuentro amoroso a través de los aromas que han quedado impregnados en las sábanas y que la devuelven a revivir cada uno de los instantes de intensa pasión:

Dejaré mis sábanas tan tocadas y regias.

$\mathrm{Y}$ tu presencia que empapó sus hilos. prolongará los goces de esta noche entre mis repetidas soledades.

Tú estarás lejos, pero tus humedades, y ese sudor ferviente,

licor rotundo en nuestras fiestas rotas, seguirán embriagando mi deseo. (2007, p.35)

En este poema, se puede apreciar la visión de un sujeto erótico activo que afirma con gran entereza su feminidad en la relación sexual. Por eso, no solo disfruta el momento, sino que trasciende los sentidos y los recuerdos. El hombre no aparece como un objeto de placer como sí aparece la mujer en muchos de los poemas de corte erótico escritos por hombres, sino como coparticipe de la relación en donde dos seres se compenetran:

Entras en mí,
quilla nunca agobiada,
como por un camino
que ya vas conociendo
y mi marea enervante

te acoge y te rodea

subversiva, tenaz, llena de peces ávidos. (2007, p. 38)

El goce que nace de esa unión es maravilloso. Cada uno es el complemento del otro. Se encuentran, se conocen y se aman hasta el infinito.

En conclusión, la poética de Dobles muestra diferentes aspectos de la vida y de su propia vida al ser en muchos casos de corte autobiográfico como ella misma lo ha sugerido "Dobles herself has admitted that her poetic inspiration is derived from biographical events of her own life and she firmely believes that it is imposible to understand fully a work of literatura without knowing at least something of the author" (Budd, 2003, p.106). El sujeto femenino se presenta de una manera muy positiva porque la poeta ha encontrado en su poesía una manera de reivindicar el papel de la mujer en la sociedad a través de su propia experiencia al poetizar en muchos temas tabúes de la sociedad. Los poemas son variados, vibrantes y pletóricos de imágenes positivas; en cada temática encuentra lo mejor del ser humano y del universo mismo; lo vive, lo saborea y lo disfruta porque está conciente que el mundo está hecho de detalles e instantes. El despertar de la conciencia al mundo circundante es el que le permite ese despertar erótico donde la lucha por la libertad sexual de la mujer todavía continúa siendo una atadura para la mujer, pero Dobles se ha permitido romper con tantas ataduras a través de su palabra.

\section{Breves conclusiones}

A través de los tiempos, la mujer ha tenido que luchar para afianzarse un lugar respetable en el campo de la literatura. Ruth Cubillo en su libro Mujeres e identidades (2001) concuerda con Magda Portal cuando expresa que la poesía siempre ha sido un género literario más propicio para las mujeres porque desde la perspectiva patriarcal "lo que tradicionalmente se ha entendido por poesía solo puede salir de "un alma de mujer", de modo que los varones que cultivan este género literario escriben poemas, nunca poesías" (2001, p.146). En otras palabras, se considera que los poemas escritos por mujeres están cargados de un gran sentimentalismo y que no poseen los mismos estándares que los masculinos. Lo cual es sinónimo de deficiencia e inferioridad. Sin embargo, las mujeres poetas se han dado a la tarea de demostrar que su capacidad de versificar puede ser tan buena o mejor que la realizada por los hombres, puesto que la calidad es independiente de su género.

Si bien es cierto, la temática o visión del universo es diferente, eso no les quita capacidad para poetizar. Este planteamiento permite concluir que la literatura escrita por mujeres en gran medida si se diferencia de la escrita por hombres puesto que las experiencias del mundo femenino son 
bastante diferentes porque "las mujeres han tenido que asumir su propia voz superando las censuras o el silenciamiento de la condición tradicional de género" (Zavala, 2011, p.21). Por esta razón, en muchas de ellas se encuentra esa poesía reveladora en donde plasman sentimientos muy personales que permiten descubrir mundos propios del ser femenino. Esta es una forma de rebelarse contra los cánones establecidos por una sociedad que se ha empeñado en mantenerlas silenciadas.

En el caso de Mía Gallegos y Julieta Dobles, ellas han jugado un papel significativo en la poesía escrita por mujeres en Costa Rica. Se han atrevido a romper con lo establecido y han superado viejas estructuras hasta llegar a obtener un espacio propio que las consolida como partes del canon literario costarricense, gracias a su excelencia. Las dos han abierto caminos para las futuras generaciones de poetas costarricenses que continúan abriéndose paso en este competitivo mundo intelectual.

\section{Bibliografía}

Berry-Bravo, Judy. (1991). Mía Gallegos: voz estelar en la lírica costarricense. Confluencia. 7 (1):144-149.

Borges, Jorge Luis. (2002). Textos recobrados 19191929. Barcelona: Emecé Editoriales.

Budd, Ruth Lorraine. (2003). Modern Spanish American Poets: First Series, Julieta Dobles Yzaguirre. Modern Spanish American Poets. 1 (1): 101-108.

Calvo, Yadira. (1993). La mujer víctima y cómplice. San José: Editorial Costa Rica.

Chen Sham, Jorge. (2003). El autorretrato en Mía Gallegos: la invención de sí misma. Istmica Revista de la Facultad de Filosofía y Letras de la Universidad Nacional.7:99-120.

Cubillo Paniagua, Ruth. (2001). Mujeres e identidades: Las escritoras del Repertorio Americano. (1919-1959). San José: Editorial de la Universidad de Costa Rica.

Díaz Zeledón, Natalia. (2015, Agosto 12). Giconda Belli: En la poesía, soy médium de una magia superior mí. San José. Entrevista en el suplemento Viva de La Nación.

Doblés Izaguirre, Julieta. (1986). Los delitos de Pandora. San José: Editorial Costa Rica.

. Amar en Jerusalén. (1992). San José: Editorial de la Universidad Estatal a Distancia.

. Hojas Furtivas. (2007). San José: Editorial Costa Rica.

Duverrán, Carlos Rafael. (1973). Poesía Contemporánea de Costa Rica, Antología. San José: Editorial Costa Rica.

Gallegos, Mía. (1985). Los reductos del sol. San José: Editorial Costa Rica. 
. (1989). El claustro elegido. San José: Editorial Universidad Estatal a Distancia.

. (1995). Los días y los sueños: Papeles de una búsqueda. San José: Editorial Costa Rica.

. (2007). El umbral de las horas. San José: Editorial Costa Rica.

Gilbert Sandra y Susan Gabar. (1998). La loca del desván: La escritora y la imaginación del siglo XIX. Madrid: Ediciones Catedra.

Hurtado Oviedo, Víctor. (2014). La palabra viva de Julieta Dobles, Premio Magón de Costa Rica. San José. http://www.nacion.com/ocio/artes/ Julieta-Dobles-Premio-Magon 1392860741. html. La Nación Virtual. 16 de septiembre 2015.

Lerner, María Luisa. (2004). Sexualidad Femenina: Mitos y Realidades. Barcelona: Editorial Paidós

Macaya Trejos, Emilia. (1992). Cuando estalla el silencio. San José: Editorial de la Universidad de Costa Rica.

Madriz Flores, Kathy. (2009). La poética de-l espacio en Hojas Furtivas de Julieta Dobles Izaguirre. Revista de Lenguas Modernas.11: 153-173.

Mora Martha Sonia y Flora Ovares Ramírez. (1994). Indómitas Voces. Las poetas de Costa Rica. Antología. San José: Editorial Mujeres.

Paz, Octavio. (1986). El arco y la lira. Sexta edición. México: Fondo de cultura económica.

Peña Bonilla, María Encarnación. (2014). La poesía desnuda el alma social de un pueblo. San José. http://www.ucr.ac.cr/noticias/2014/02/24/lapoesia-desnuda-el alma-social deunpueblo. htm. Universidad de Costa Rica, San José. 18 de agosto 2015.
Solano, Andrea. (2015). "Las mujeres aún no hemos logrado pariedad en las letras: Entrevista con Magda Zavala". http://www.nacion.com/ocio/ artes/mapa-escritura femenina creando.htm. La Nación Virtual. 18 de marzo de 2015.

Vallbona, Rima de. (1992). De la poesía intimista al lirismo trascendental. Alba de América. 10 (18-19): 273-288.

- (1990). Trayectoria Actual de la poesía femeninita en Costa Rica. La poesía costarricense. San José: Editorial Costa Rica.

Zavala, Magda. (2011). Investigación, estudio introductorio, selección de autoras y obras, notas y apéndices. Con Mano de mujer. Antología de poetas centroamericanascontemporáneas (1970-2008). San José: Editorial Fundación Interactes. 